\title{
Effectiveness of Gully Erosion Control Measures in Edo State, Nigeria
}

\author{
Augustine Osayande ${ }^{*}$, Williams W. Edobor ${ }^{2}$, Sako Kato $^{1}$ \\ ${ }^{1}$ Department of Geography and Environmental Management, University of Abuja, Abuja, Nigeria \\ ${ }^{2}$ Department of Geography and Environmental Management, Ambrose Alli University, Ekpoma, Nigeria \\ Email: *austinelande@yahoo.com, sakokato@gmail.com, edoborwilliams@aauekpoma.edu.ng, edoborwilliams@gmail.com
}

How to cite this paper: Osayande, A., Edobor, W.W. and Kato, S. (2019) Effectiveness of Gully Erosion Control Measures in Edo State, Nigeria. Open Access Library Journal, 6: e5018.

https://doi.org/10.4236/oalib.1105018

Received: November 1, 2018

Accepted: March 9, 2019

Published: March 12, 2019

Copyright $\odot 2019$ by author(s) and Open Access Library Inc.

This work is licensed under the Creative Commons Attribution International License (CC BY 4.0).

http://creativecommons.org/licenses/by/4.0/

\begin{abstract}
The study examined the effectiveness of Gully Erosion Control Measures in Edo State, Nigeria. The objectives are to investigate erosion prone areas in Edo State; the measure(s) were adopted to control gully erosion in the area and the effectiveness of the adopted measures across the study area. The research adopted questionnaire administration and direct field observation as methodological approach. It was observed that control measures put in place in the study area include mechanical methods of back filling, sand bagging, construction of channels and construction of speed breakers. The biological control methods in use are trees and crop planting. These control measures as observed during the fieldwork are partly successful as pointed out by respondents in their respective zones. Therefore, there is an urgent need to address this emerging looming disaster in the State.
\end{abstract}

\section{Subject Areas}

Edaphology

\section{Keywords}

Edo, Magnitude, Gully, Volume, Soil, Loss, Remedies

\section{Introduction}

Gully Erosion is caused by unwise human activities such as deforestation, overgrazing, and unplanned construction activities. Gully erosion problems whether they are huge or small can definitely be controlled and prevented. Gully erosion control measures are usually grouped into two categories: agronomic and engineering. Agronomical control method provides the soil with physical protection against scour and in slowing down the velocity of flow by increasing the hydrau- 
lic resistance of the channel [1]. Controlling of erosion means reducing the rate of eroded soil to it barest minimal. According to [2], before any actions are taken to correct soil erosion, there is need for proper understanding of the causes. Without understanding the causes of soil erosion, any control measures taken may be waste of time and money which may even worsen the problem. [1] observed that experts from the field of Conservation, Geomorphology, Soil Geography, Forestry and Agriculture have recommended some control measures in various parts of the world. These control measures have been successful in some areas and unsuccessful in other areas. The need for sustainable soil erosion control depends on the study and understanding of several conservation strategies. Soil erosion is a serious problem in Africa due to several factors responsible.

Soil erosion as a problem in Africa has been attributed to numerous causes such as tropical deforestation, overgrazing, agricultural intensification, urbanization and low soil fertility [1]. With the continue consequences of soil erosion problems, assessing merits and limitations of different control measures is a topical issues that are of great concern because of the ever-shrinking prime land resources and deteriorating environmental quality. This global concern for soil erosion problem is because soil as a resource is non-renewable in the human time scale. From an ecological and economic standpoint, soil erosion is probably the most serious environmental problem facing land resources in Nigeria. [3] suggests that the dangers have become progressively more serious as there are undue pressures on land by agriculturist. This is as a result of increase in both human and animal population with consequent urbanization, deforestation and over exploitation of land resources. Studies of soil erosion in the country have been undertaken by different researchers. According to [4] much has been said and written about soil erosion in different parts of Nigeria. [5], observed that there are areas where the causes and impact are the major concern but there is need to look at the effectiveness of the control measures that are put in place.

The control and prevention of soil erosion rely upon the selection of appropriate control measures and conservation strategies. Gully erosion as a form of soil erosion is an environmental disaster currently plaguing lands that would have otherwise been used for infrastructural developments. [6] observed that the handling, controlling and monitoring of soils in Benin City must be geared towards achieving quality environment for man. This is because soil erosion in the area is caused by a multidimensional factor. According to [7], one of the main causes of gully erosion in Edo State is road construction with inappropriately terminated drainage network. This is because gullies that develop due to this poor road construction are allowed to get to a worst state before solutions are sorted for by individuals, corporate organizations and government.

\section{Study Area Description}

Edo State is located in the South-South Zone of Nigeria. Its capital is Benin-city. The State was created in 1991 out of the old Bendel State and its geographical 
coordinates are Latitudes $05^{\circ} 44^{\prime}$ to $07^{\circ} 34^{\prime} \mathrm{N}$ and longitude $05^{\circ} 04^{\prime}$ and $06^{\circ} 45^{\prime} \mathrm{E}$. It has a land mass of 19,794 km square and from Figure 1 it is bordered by Kogi State to the north, Delta State to the East and South and Ondo State to the West. The state consists of eighteen Local Government Areas which include Akoko-Edo, Egor, Esan Central, Esan North-East, Esan South-East, Esan West, Etsako Central, Etsako East, Etsako West, Igueben, Ikpoba-Okha, Oredo, Orhionmwon, Ovia North-West, Ovia South-West, Owan East, Owan West and Uhunmwonde.

The relief of the area is mainly characterized by swamping creeks and dissected plateau such as the Esan Plateau, Orle valley and the dissected uplands of Akoko-Edo Local Government Area. According to [8], there are six types of physical features which constitute the landscape of the area. Sandy coastal plain and alluvium clay are found in the Benin lowlands area with some hills in the east. Slopes are tilled in the southwest direction. River Osse, River Orihionmwon and lkpoba are the major drain in the area.

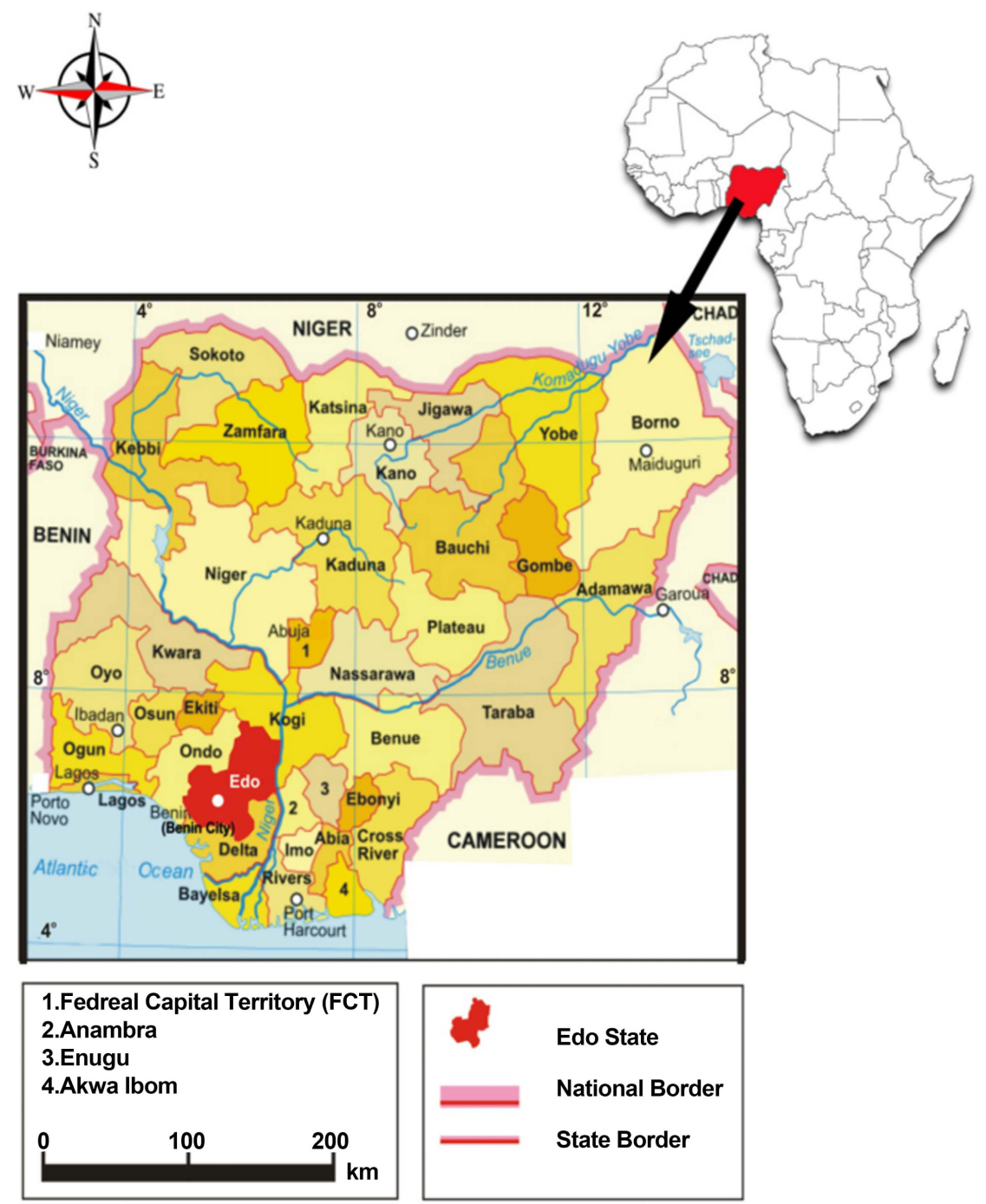

Figure 1. Location of Edo State in Nigeria. Source: Modify From Nigeriazipcodes.com. 
According to [6], the state has land mass that is relatively flat terrain in the southern part with an average height above the sea level of about 500 metres except towards the northern axis where the Northern and Esan plateaus range from 183 metres at the Kukuruku Hills and 672 metres at the Somorika Hills. [6], observed that slopes of varying gradients exist in the state and this contributes to the problem of gully erosion in the state. It has been estimated that land loss due to gully erosion, sheet-rill erosions in the study area constitute about $5 \%$ degraded land [7].

Soil type in the study area is generally the red-yellow kind of Ferralsols. In Akoko-Edo the variation consists of shallow and stony reddish clay at the feet of inselbergs in the higher sections [9]. Lateritic clay and fine grained are found in the upper slope and lateritic tablelands while ferruginous soils and crystalline acid rocks at the basement complex. Gully erosion develops rapidly in most parts of the area due to the urbanization and terrain covered by friable and highly erodible soil deposits.

\section{Methodology}

For the purpose of this research and to be able to meet the objectives of the work, primary data was used. This includes direct field observation gully erosion control and supported by questionnaire administration. In administering the questionnaire, the purposive sampling technique was used. This technique was chosen because gully erosion affects some specific areas of the state and not all the people in the study area are affected by gully erosion. The questionnaire was administered to people who are directly affected by gully erosion within $5 \mathrm{~km}$ radius of the chosen gullies site. This is to ensure that the respondents are those affected by gully erosion problem. Due to the nature of the study, considering time, cost and convenience, a copy of the questionnaire was administered to 30 respondents at the chosen 16 gully sites making a total of 480 respondents considered in the course of this research. Ikabigbo Gully, Jatu Road Gully, Egelessor Gully and GazMomoh Gully in Edo North, Oka Gully, Ikpoba Slope Gully, Queen Eden Gully, Ogiso Gully Erosion, Evbotubu Gully and University of Benin Gully in Edo South while Ambrose Ali University Gully (Ekpoma), IdmogoIgueben Gully, Ewohimi Gully, Uromi Gully, Ewu Gully and Ibore Gully are in Edo Central.

\section{Results and Discussion}

The control measures used by community in the area include tree and crops planting, sand bagging and speed breakers, back filling and construction of drainage or channels. The response on control measures used by community members in the area are presented in Table 1 . The various measures and their statistical figures are shown for Edo North, South and Central zones. Table 1 demonstrates that, majority (63\%) prefer the use of channel construction for proper erosion control in Northern part of Edo State, followed by $26 \%$ who use vegetation (crops and trees) to control erosion in their area. Table 2 demonstrates 
Table 1. Response on control Measures of gully erosion in Edo North.

\begin{tabular}{lcccccc}
\hline Control measures & Ikabigbo & Jatu Road & Egelessor & GazMomoh & Total & Percentage \\
\hline $\begin{array}{c}\text { Cultivation along } \\
\text { contours }\end{array}$ & - & - & - & - & - & - \\
$\begin{array}{c}\text { Trees/crops } \\
\text { planting }\end{array}$ & 24 & - & - & 6 & 30 & $26 \%$ \\
$\begin{array}{c}\text { Sand bagging/speed } \\
\text { breakers }\end{array}$ & 4 & - & 2 & - & 6 & $5 \%$ \\
$\begin{array}{c}\text { Control of animal } \\
\text { grazing }\end{array}$ & - & - & - & - & - & - \\
$\begin{array}{c}\text { Back filling } \\
\text { Construction of } \\
\text { channels }\end{array}$ & - & - & - & 6 & 6 & $5 \%$ \\
$\quad$ Total & 30 & 28 & 28 & 28 & 114 & $100 \%$ \\
\hline
\end{tabular}

Table 2. Response on control measures of gully erosion in Edo South.

\begin{tabular}{|c|c|c|c|c|c|c|c|c|}
\hline Control measures & Oka & Ogiso & $\begin{array}{l}\text { Ikpoba } \\
\text { slope }\end{array}$ & $\begin{array}{l}\text { Queen } \\
\text { Eden }\end{array}$ & Evbotubu & Uniben & Total & Percentage \\
\hline $\begin{array}{l}\text { Cultivation along } \\
\text { contours }\end{array}$ & - & - & - & - & - & - & - & - \\
\hline Trees/crops planting & 18 & 14 & 18 & - & - & 4 & 54 & $31 \%$ \\
\hline $\begin{array}{c}\text { Sand bagging/speed } \\
\text { breakers }\end{array}$ & 10 & 12 & 12 & - & 10 & - & 44 & $25 \%$ \\
\hline Control of animal grazing & - & - & - & - & - & - & - & - \\
\hline Back filling & - & - & - & 16 & - & 26 & 42 & $24 \%$ \\
\hline Construction of channels & - & - & - & 14 & 20 & - & 34 & $20 \%$ \\
\hline Total & 28 & 26 & 30 & 30 & 30 & 30 & 174 & $100 \%$ \\
\hline
\end{tabular}

that respondents in Edo South have variety of choices spreading from those who prefer crops and tree planting (biological) (31\%) to those who like to use sandbags and speed breaker (25\%) and those in favour of back filling process (24\%) for the control of erosion. Table 3 demonstrates that the situation in the Central Zone of Edo State revealed that about $81 \%$ prefer using either biological control measures $(41 \%)$ or mechanical construction of drainage channels (40\%), while only $18 \%$ prefer sand bagging and speed breakers as means of erosion control.

The responses on the effectiveness of the control measures are presented in Tables 4-6 for Northern, Southern and Central Edo State. The effects of these measures are the perceptions of the respondents based on their preferred methods of gully erosion control. In Northern Edo State, Table 4 demonstrates that about $58 \%$ consider their control measures to be slightly effective not effective is $19 \%$ while $21 \%$ think they are effective. Only less than $2 \%$ see the control methods as very effective. In Southern Edo State, Table 5 demonstrates that $30 \%$ of the respondents consider their measures as not being effective, while about $39 \%$ consider the measures either slightly and (31\%) said it is effective. Table 6 demonstrates that respondents of Central Edo are of the views that the measures 
Table 3. Response on control measures of gully erosion in Edo Central.

\begin{tabular}{ccccccccc}
\hline Control measures & AAU & Igueben Ewohimi & Uromi & Ewu & Ibore & Total Percentage \\
\hline Cultivation along contours & - & - & - & - & - & - & - & \\
Trees/crops planting & 20 & 14 & 8 & 18 & 8 & - & 68 & $41 \%$ \\
Sand bagging/speed breakers & 6 & 2 & 20 & 2 & - & - & 30 & $18 \%$ \\
Control of animal grazing & - & - & - & - & - & - & - & - \\
Back filling & - & - & - & - & 2 & - & 2 & $1 \%$ \\
Construction of channels & 4 & 10 & - & 8 & 16 & 28 & 66 & $40 \%$ \\
Total & 30 & 26 & 28 & 28 & 26 & 28 & 166 & $100 \%$ \\
\hline
\end{tabular}

Table 4. Response on effectiveness of control measures in Edo North.

\begin{tabular}{cccccc}
\hline & Not Effective & Slightly Effective & Effective & Very Effective & Total \\
\hline Ikabigbo & 6 & 22 & 2 & - & 30 \\
Jatu road & 8 & 20 & - & - & 28 \\
Egelessor & 8 & 18 & 2 & - & 28 \\
GazMomoh & - & 6 & 20 & 2 & 28 \\
Total & 22 & 66 & 24 & 2 & 114 \\
Percentage & $19 \%$ & $58 \%$ & $21 \%$ & $2 \%$ & $100 \%$ \\
\hline
\end{tabular}

Table 5. Response on effectiveness of control measures in Edo South.

\begin{tabular}{cccccc}
\hline & Not Effective & Slightly Effective & Effective & Very Effective & Total \\
\hline Oka & 8 & 12 & 8 & - & 28 \\
Ogiso & 14 & 12 & - & - & 26 \\
Ikpoba Slope & 14 & 16 & - & - & 30 \\
Queen Eden & 12 & 8 & 10 & - & 30 \\
Evbotubu & 4 & 8 & 18 & - & 30 \\
Uniben & - & 12 & 18 & - & 30 \\
Total & 52 & 68 & 54 & - & 174 \\
Percentage & $30 \%$ & $39 \%$ & $31 \%$ & - & $100 \%$ \\
\hline
\end{tabular}

Table 6. Response on effectiveness of control measures in Edo Central.

\begin{tabular}{cccccc}
\hline & Not Effective & Slightly Effective & Effective & Very Effective & Total \\
\hline AAU & 4 & 26 & - & - & 30 \\
Igueben & 2 & 20 & 4 & - & 26 \\
Ewohimi & 6 & 14 & 8 & - & 28 \\
Uromi & 8 & 10 & 10 & - & 28 \\
Ewu & 16 & 10 & - & - & 26 \\
Ibore & 10 & 16 & 2 & - & 28 \\
Total & 46 & 96 & 24 & - & 166 \\
Percentage & $27 \%$ & $58 \%$ & $15 \%$ & - & $100 \%$ \\
\hline
\end{tabular}


are not effective (27\%) while $58 \%$ think they are either slightly effective or effective (15\%) (Figures 2-5).

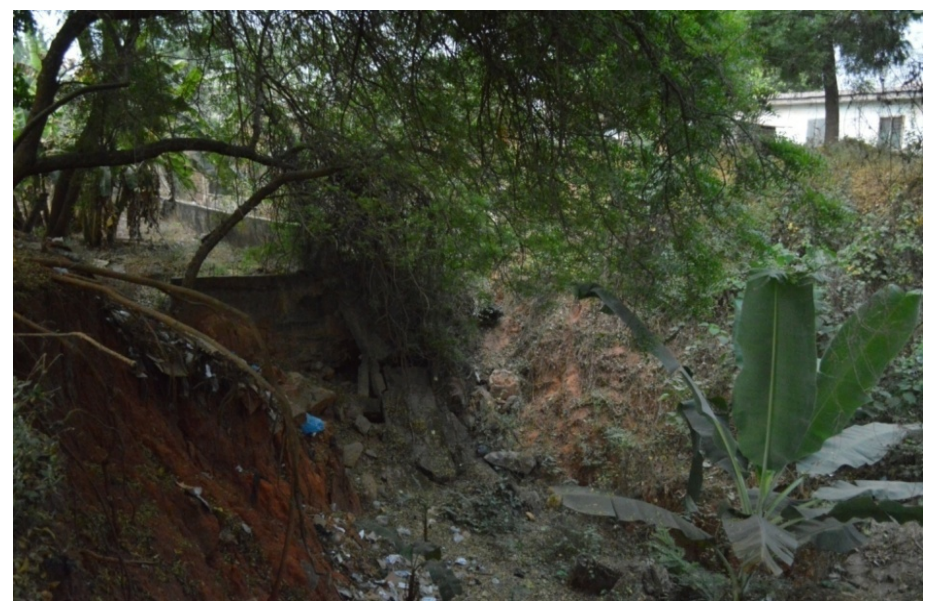

Figure 2. Shows uses of neem trees and plantain as control measure at Ikabigbo Gully in Edo North (Biological Control measures).

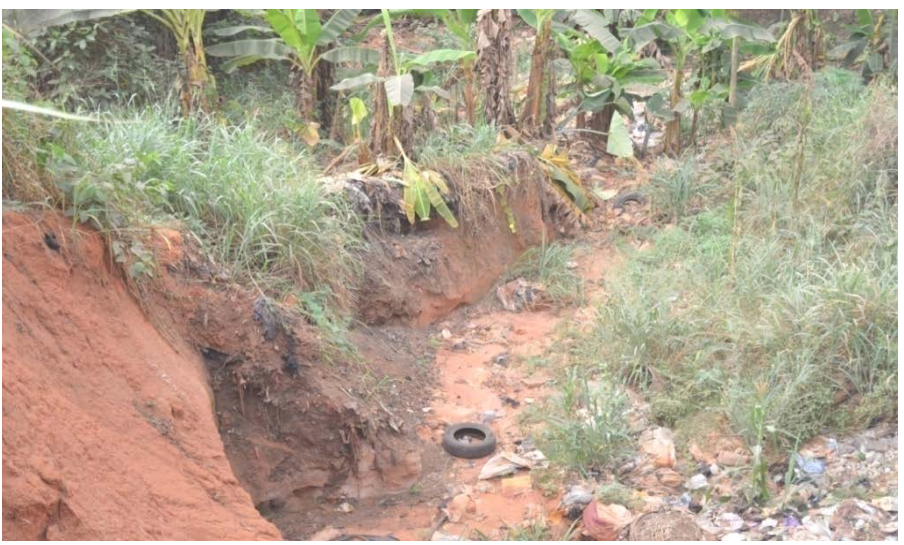

Figure 3. Shows use of plantain as control measure at Ikpoba slope gully in Edo South (Biological Control methods).

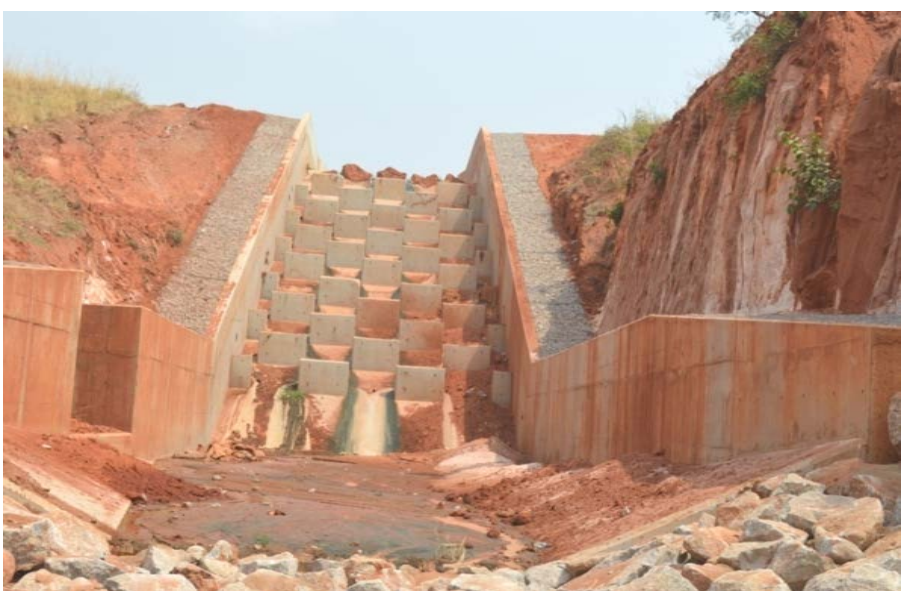

Figure 4. Shows use of speed breakers as control measure at GazMomoh Gully in Edo North (Mechanical methods). 


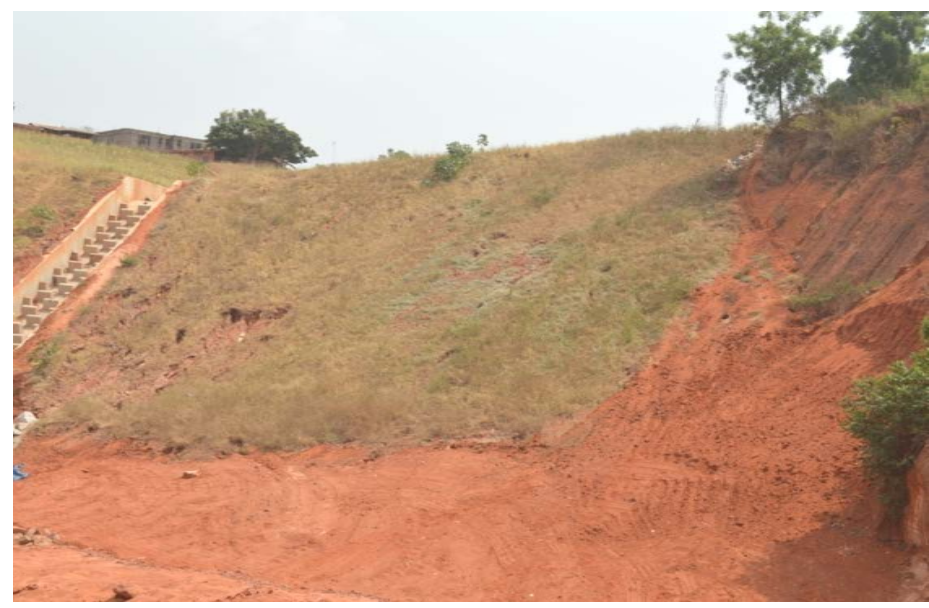

Figure 5. Shows use of rice grass as control measure at GazMomoh Gully in Edo North (Mechanical and Biological measures).

\section{Conclusion and Recommendations}

Gully erosion is a recurrent form of soil erosion which is difficult and expensive to control. It is better to prevent its initiation than to control it. Control measures put in place in the study area include mechanical methods of back filling, sand bagging, construction of channels and construction of speed breakers. The biological control methods in use are trees and crop planting.

These control measures as observed during the fieldwork are partly successful as pointed out by respondents in their respective zones. Therefore, there is an urgent need to address this emerging looming disaster in the State. As suggested by [7], current control measures should include redesign and upgrading of existing drainage infrastructure, and provision of gully control measures at the gully heads that can prevention further elongation and expansion and thus protect the environment from further degredation. The presence of NEWMAP in the State is a good sign that government is being proactive in the tackling the menace of gully erosion in the State seriously putting in place some control measures; a lots of resource are needed to bring the gully erosion phenomenon in the State to some level of stability. For effective implementation of the control measures, the local communities should be involved and carried along at all stages of the NEWMAP intervention programmes.

The perception of the communities has been brought to light as they see the effectiveness of the current efforts at controlling the gully erosion problems. Base on the findings, the following recommendations are necessary in order to arrest further loss of land, buildings and other properties in the study area.

Civil works such as erection of retaining walls, use of erosion brakes, construction of side drains, construction of channels and back-fillings should be associated with biological measures such as planting of trees and crops along erosion prone areas.

There is need for various agencies such as Department of Erosion, Flood Control and Coastal Zone Management, Federal Ministry of Environment, Ni- 
geria Hydrological Services Agency (NIHSA), Federal Ministry of Water Resources, Nigeria Erosion and Watershed Management Project (NEWMAP) River Basin Development Authorities (RBDAs) and States Ministry of Environment to embark on continuous monitoring of control measures that are been used in the area.

Social-economic problems resulting from gully erosion disaster in the area should be address. This will help to reduce the undue pressure on soil in the study area.

It is also important to review relevant environmental laws and policies to make them suitable for the present and anticipated soil erosion problems. Mechanical control measures such as culverts, drainages and speed breakers should be considered with knowledge of hydraulic actions.

There is need for establishment of Erosion Monitoring Post (EMP) in the tree geopolitical zones in the study area. This will increase the capacity for monitoring soil resources and early response to problem of gully erosion in the study area. Involvement of local community especially in implementation of control measures would improve on the level of their effectiveness. Policy makers must work with expert with knowledge of environmental management in efforts to tackle the gully erosion problems in the study area; this is necessary because soil is virtually a non-renewable resource.

\section{Conflicts of Interest}

The authors declare no conflicts of interest regarding the publication of this paper.

\section{References}

[1] Lal, R. (1988) Monitoring Soil Erosion from Tropical Arable Lands and Its Control. Advances in Agronomy, 37, 183-248. https://doi.org/10.1016/S0065-2113(08)60455-1

[2] Abubakar, S.M. (1996) Rehabilitation of Degraded lands by Means of Fallowing in a Semi Arid Area of Northern Nigeria. Land Degradation and Development, 7, 133-144.

[3] Dudley, S. (2000) Land Utilization and Soil Erosion in Nigeria. Geographical Review, 28, 35-36.

[4] Areola, O. (1999) The Good Earth: Inaugural Lecture. University of Ibadan, Ibadan.

[5] Blaikie, P. (1991) Decentralisation and Participation in Soil and Water Conservation. New Opportunities and New Problems. ITC Journal, 4, 281-285.

[6] Eseigbe, J.O. and Ojeifo, M.O. (2012) Aspects of Gully Erosion in Benin City Edo State, Nigeria. Research on Humanities and Social Sciences, 2, 22-26.

[7] Ehiorobo, J.O. and Izinyon, O.C. (2011) Measurement and Documentation for Flood and Erosion Monitoring and Control in Niger Delta Region of Nigeria. Journal of Emerging Trends in Engineering and Applied Sciences, 3, 1-14.

[8] Aderemi, A. and Iyamu, F. (2013) Risk Assessment Analysis of Accelerated Gully Erosion in Ikpoba Okha Local Government Area of Edo State. Nigeria Environment and Natural Resources Research, 3, 68-76. 
[9] Idehai, I.M. and Egai, A.O. (2014) Aspects of Geophysical Exploration Using Vertical Electrical Sounding (VES) for Groundwater in Parts of University of Benin, Benin City. Nigerian Journal of Applied Sciences and Environmental Management (JASEM), 18, 21-28. 